\title{
Post-Disaster Mitigation and Recovery in Tourism Destinations: Learning from The Lombok Earthquake
}

\author{
Sri Maryanti*1, I Gusti Ayu Oka Netrawati ${ }^{1}$, I Gusti Putu Bagus Suastina ${ }^{1}$, Febrian Humaidi Sukmana², \\ Dwi Martini ${ }^{3}$ \\ 1Departement of Management, Sekolah Tinggi Ilmu Ekonomi 45 Mataram, Nusa Tenggara Barat, Indonesia \\ 2Departement of Business Administration, Universitas Nahdlatul Wathan Mataram, Nusa Tenggara Barat, \\ Indonesia \\ ${ }^{3}$ Departement of Business Law, Universitas Mataram, Nusa Tenggara Barat, Indonesia
}

\begin{abstract}
Article Info

Volume 8, Issue 2

Page Number : 571-584

\section{Publication Issue}

March-April-2021

\section{Article History}

Accepted : 20 April 2021

Published : 26 April 2021

This research's main objective is to study various patterns of collaboration between stakeholders (central and local governments, tourism industry players, and affected communities) in the post-earthquake mitigation and recovery processes in tourist destinations in West Nusa Tenggara. This research methodologically uses a literary study approach. The relevant information has been collected from various news sources from electronic media, and then the information is arranged chronologically and thematically so that it can be studied further. In the research results section, we describe flashbacks of the Lombok earthquake disaster and then explain what has been done by the stakeholders. Finally, what should be done next in the post-disaster tourism destination recovery agenda? This study's insights may help policymakers, tourism businesses, and affected communities consider strategic collaborative measures in post-disaster recovery.
\end{abstract}

Keywords : Stakeholder Collaboration; Disaster Management; Earthquake; Tourism Industry; Lombok-West Nusa Tenggara

\section{INTRODUCTION}

The tourism industry in recent decades has received much attention and is one of the leading industries in the world [1]. As one of the largest economic sectors globally, tourism supports one in ten jobs worldwide and generates $10.4 \%$ of world GDP (www.wttc.org). In 2018, the travel and tourism industry experienced a growth of $3.9 \%$, compared to the global economy
(3.2\%). The industry created one in five new jobs in the past five years (www.wttc.org). For many countries globally, tourism has become the primary income source [3]. However, the tourism industry is more prone to disasters than other industries [4]. Natural and cultural resources are usually seen as the leading tourism product; however, the severe damage generated after a disaster can affect tourism demand leading to a decline in economic activity. 
As mentioned briefly above, the tourism industry is one of the industries most vulnerable to disasters because it is very dependent on natural resources; in other words, the threat of natural disasters can come at any time and may not be avoided [5]. The United Nations International Strategy for Disaster Reduction (UNISDR) reports that the accumulated economic damage caused by the disaster has reached $\$ 1.4$ trillion from 2005 to 2014. The number of people affected is also vast [6]. UNISDR [7] defines a disaster as "a serious disturbance to the functioning of a community or society that causes widespread human, material, economic or environmental harm that exceeds the ability of the affected community/community to cope with its resources" (p. 13). It was noted that in many cases reported, both the government and the tourism industry encountered obstacles and difficulties in overcoming the disaster [8] because it is difficult to predict and usually brings significant adverse effects [9]. In responding to disasters, effective inter-agency collaboration is essential for tourism response and recovery and requires ongoing efforts to maintain and develop collaborative relationships [10]. The tourism industry itself is a complex mix of many stakeholders; therefore, a strong network of cooperation and wellcoordinated joint efforts can help accelerate the recovery of post-disaster adverse effects [11].

The recent earthquake disaster in Lombok Island, West Nusa Tenggara (especially in North Lombok Regency and West Lombok Regency) is a case example of how a disaster significantly affects the tourism sector disrupts economic activity, both micro and macro. The earthquake disaster resulted in a significant decrease in tourist visits (both domestic and foreign)(disbudpar.ntbprov.go.id). The impact can be more severe due to this industry's characteristics, namely the interdependence of industry players as a business chain, such as restaurants, transportation entities, accommodation, and attractions [9]. Imagine if one tourism business chain does not function, it is very likely that it will affect the entire industrial ecosystem. The nature of the interconnectedness and interdependence between various stakeholders has resulted in a complex and dynamic environment for the tourism industry [13]. Therefore, cross-sectoral stakeholder collaboration is crucial to managing industry events [14], especially when dealing with natural disasters that significantly affect the tourism industry [15].

This paper's main objective is to study various patterns of collaboration between stakeholders and make the Lombok earthquake disaster a case study. Next, we examine various literature that discusses how stakeholder collaboration and its impact on effective tourism disaster management (especially post-disaster). However, research on this topic has received much attention at the international level. However, to the best of our knowledge, particularly in West Nusa Tenggara itself, there have not been many similar studies conducted. In other words, studies on this topic have the potential to contribute to knowledge development and provide a practical overview of taking sensible steps in disaster management in a tourist destination such as West Nusa Tenggara Province. We seek to collect and review various reports and relevant literature, primarily related to how stakeholders in the tourism industry coordinate and collaborate and identify barriers that affect coordination and collaboration in tourism disaster management. The insights from this study may help policymakers, tourism business actors and communities affected by the disaster to be able to consider strategic steps in post-disaster recovery, especially in the region of Lombok Island, West Nusa Tenggara. At the same time, we are identifying barriers affecting coordination and collaboration in tourism disaster management. The insights from this study may help policymakers, tourism business actors and communities affected by the disaster to be able to consider strategic steps in post-disaster recovery, especially in the region of Lombok Island, West Nusa Tenggara. In contrast, they were identifying barriers affecting coordination and collaboration in tourism 
disaster management. The insights from this study may help policymakers, tourism business actors and communities affected by the disaster to be able to consider strategic steps in post-disaster recovery, especially in the region of Lombok Island, West Nusa Tenggara.

The systematics of this paper can be described as follows. As a first step, we briefly describe why this research is essential to do. Presentation of data and some crucial narratives to strengthen arguments regarding this research's importance are presented in the introduction. In the next section, a brief literature review is presented that collects various discussions about stakeholder collaboration and disaster management, especially in the tourism industry. In the method section, we explain why we use literature studies to achieve our research objectives. As for the discussion section on our research results, we divide them into three sub-discussions, consisting of (i) flashbacks of the Lombok earthquake disaster, (ii) what have been done by the stakeholders? (iii) what to do next? In the end, we provide conclusions related to the topics studied.

\section{LITERATURE REVIEW}

\section{Stakeholders Collaboration}

Stakeholders are defined as individuals, groups, or organizations interested in the same problem, which can influence or be influenced directly by actions taken by other parties to achieve goals or solve problems [16]. Stakeholder involvement has become an essential requirement for effective and efficient risk governance [17]. Therefore stakeholder collaboration is recognized as an essential part of tourism destination planning and management. However, not all destination stakeholders have the same level of power and influence in collaborative activities or decision-making, with some groups exert more influence over the process [18]. A good understanding of the interdependence between organizations in disaster management is needed to facilitate collaboration, especially collaboration that focuses on technical aspects [19].

Collaboration itself is described as a collaborative decision-making process among the main stakeholders of a problem domain [16] which combines the diverse views of diverse and interdependent stakeholders [13]. The main objective of stakeholder collaboration is to achieve mutual interests and benefits and resolve problems and obstacles. Jamal and Stronza [13] note the various problems and barriers that collaboration can overcome in tourism management. However, even though stakeholder collaboration has been widely recognized as an essential element in effective tourism disaster [15], [20], [21]. Unfortunately, the application in various places and conditions is still relatively weak.

Previous research claims that Destination Management Organizations (DMOs) can actively foster collaboration between stakeholders, which is key to ensuring destination competitiveness [22]. Jiang and Ritchie [5] identify how stakeholder collaboration is currently being studied, for example, from a "collaborative governance" perspective [23], "Cross-sector collaboration" [24], and "collaborative partnerships" [25]. This collaboration model usually shows clear collaboration stages, such as (i) the collaboration formation stage, (ii) the collaborative process stage, and (iii) the results and reflection stage. In the collaborative building stage, building collaborative relationships between stakeholders is highlighted, such as initial conditions, institutional design, direct antecedents, and activity/activity environment [23]-[25]. In the collaborative process stage, other models focus on the steps in the collaboration operation, the main actions in the collaborative process, and the important role of collaborative communication (see [23]-[25]).

\section{The Collaboration of Stakeholders in Tourism "Disaster Management"}


The majority of studies on stakeholder collaboration in tourism disaster management were carried out in the 1990s. After the 21st century, most studies have focused on recovery strategies for a single tourism business/organization or a single purpose rather than building regional collaborations for disaster management. Besides, most of the stakeholder collaboration studies in tourism focus on sustainable tourism development and community-based tourism planning under normal conditions [26]-[29], the fact is that there is little literature that covers the management of extreme events such as disasters in the tourism sector. Although some tourism researchers have studied collaborative disaster management in tourism [30], the adoption of the concept of stakeholder collaboration is still lacking. Scarpino and Gretzel [31] highlighted the importance of multiple groups that "must" work together to overcome barriers during a crisis/disaster by addressing critical resources and stakeholder relationships (particularly collaboration with external parties). On this topic, tooScarpino and Gretzel [31] found that empirical studies are lacking. This finding is certainly surprising given the importance of stakeholder collaboration for effective tourism disaster recovery.

In the context of tourism disaster management, Fyall, Garrod, and Wang [32] have classified several theoretical perspectives to understand stakeholder collaboration. Three types of the theory were identified as the basis and motivation for stakeholder collaboration, namely (i) resource-based theories, (ii) relationship-based theories, and (iii) politics-based theories. Based on the classification and further explanation by Pennington-Gray et al. [20], the following section briefly discusses the theories that will help understand collaboration in tourism disaster management.

The resource-based theory focuses on using available resources to form collaborative efforts with other entities [20], [33]. This theory recognizes limited resources and the need to acquire resources through collaboration, which provides a rationalization for trusting collaboration [32]. Cioccio and Michael [34] believe that sharing knowledge/information and obtaining financial support from the government is necessary for community collaboration after a disaster. Resource sharing is considered the basis of stakeholder collaboration applicable to tourism disaster management [35], [36]. This opinion is based on the tourism business's characteristics, namely that business actors in this sector are small businesses with a more uncertain resource base. The impact of resource loss is even more severe after natural disasters as businesses suffer asset loss/damage and a significant reduction in revenue in the tourism sector [37]. These tourism business actors can have cash flow problems and are more motivated to collaborate to source resources from other people. These shared resources include tangible assets such as financial support and collaborative capital and intangible assets, such as information, knowledge, and capabilities [35].

The relationship-based theory is driven by the recognition of interdependence and the need to exchange mutual interests [38]. The relationalexchange theory is based on the best interest of organizations working in the same problem area to solve common problems by developing a joint management structure [33]. Natural disasters usually bring significant physical and reputational damage to the tourism industry, a common problem for all stakeholders. Besides, network theory suggests that organizations can be motivated to collaborate from their past collaborative experiences to interact with other organizations [36]. Guo and Pickles [39] found that organizations with broader networks and positive past experiences were more likely to collaborate formally, which also applies to tourism disaster management.

Meanwhile, the political-based theory explores the nature of power in society [16] and measuring the balance of power between states, organizations, 
groups and individuals [40]. Fyall, Oakley and Weiss [41] suggest that political theory is used to observe power dynamics and the distribution of benefits among stakeholders in the context of collaboration. Pennington-Gray et al. [33] use this theory to identify who can control the resources that affect the successful collaboration for tourism disaster management. Howes et al. [42] further demonstrate that the concepts of joint governance and network governance can be used to enhance policy integration. Based on this theory, the government's role is crucial in building stakeholder collaboration for tourism disaster management/management.

\section{RESEARCH METHODS}

As mentioned at the end of the introduction above, this research methodologically uses a literary study approach. There are many reasons for conducting a literature review, one of them and perhaps the foremost being to make sure that the researcher knows what should be done and ensure that the review does not miss the vital knowledge required. A literature review is a written assessment of what is already known or existing knowledge about a topic [43]. The primary purpose of a literature review is to gather and collect the ideas and knowledge of others/other parties that have been studied previously [44]. A literature review is intended to review what has been done and is known regarding a particular topic, then rearrange the information in a relevant and critical way.

For this research, we collect various relevant information through the news media (especially online media) then compile the information chronologically for further study. Various other sources of information, for example, journal articles, textbooks, websites and other documents. Were examined to learn how the existing and "possible" stakeholder collaboration schemes could be adopted and implemented for post-disaster mitigation and recovery efforts in West Nusa Tenggara. So it can be concluded, the use of literature review as used in this study is intended to gain adequate knowledge and understanding of how stakeholders in the tourism sector collaborate in post-disaster mitigation and strive to present steps that have been and will be taken to enhance effective collaboration. Such understanding can help stakeholders in the tourism industry evaluate mitigation strategies and promote practical efforts to restore tourism destinations.

\section{RESULTS AND DISCUSSION}

\section{Flashback of the Lombok Earthquake Disaster}

This section aims to provide important information related to the earthquake disaster that occurred on the island of Lombok (and part of the island of Sumbawa) and other information that is an integral part of the discussion in this study. The presentation style is deliberately arranged chronologically; this is intended to make it easier for readers to know and understand when, where and how the Lombok earthquake disaster.

The following shows the earthquake report's details $(\mathrm{M} \geq 5.0)$ released by BMKG from 29 July 2018 to 11 September 2018.

Figure 1. Details of the Earthquake $(M \geq 5.0)$

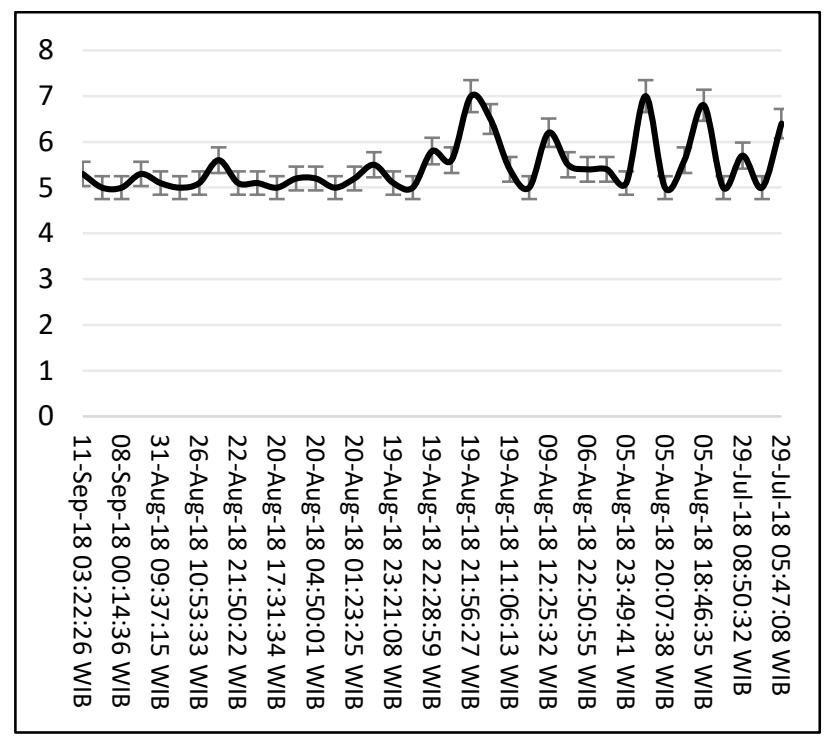

Source: BMKG 2018 (data is summarized) 
Sunday, 29 July 2018, at 05.47 WIB, a tectonic earthquake measuring 6.4 on the Richter scale occurred (BMKG, 2018a), making people panic, especially East, West and North Lombok. It seems that the earthquake was not only felt throughout the island of Lombok, parts of Bali and Sumbawa also felt the earthquake (although with a smaller shock intensity). The National Disaster Management Agency (BNPB) and the National Search and Relief Agency (BASARNAS) immediately acted for prevention and relief efforts and search for earthquake victims (both dead and injured). In this emergency condition, one of the locations that received attention from the government, followed up by the rescue team, was the tourist destination of Mount Rinjani, which was packed with climbers. To evacuate about 1,200 climbers (both residents (www.bbc.com, 2018), The Army Special Forces Command (Kopassus) was also involved in the evacuation process. After the earthquake, the Regional Government of West Nusa Tenggara Province immediately issued a policy to close all forms of activity in Mount Rinjani National Park. This step is taken to minimize the risk of "potential hazards" that may arise after the earthquake [47].

On 5 August 2018, to be precise, at $18.46 \mathrm{WIB}$, Lombok was again shaken by an earthquake with a magnitude of 7.0 SR. This earthquake by BMKG claimed to be the main earthquake in a series of earthquakes on Lombok Island since the initial earthquake measuring 6.4 on the Richter scale. Unlike the impact of the previous earthquake, in addition to its greater strength (greater destructive power), the BMKG also issued an early warning of the potential for a tsunami (for the coastal areas of North Lombok, northern West Lombok and northern East Lombok). Of course, this information makes the entire community on Lombok panic (both local people and tourists who are enjoying a vacation). People and tourists have flocked to stay away from the shoreline to a place that is considered relatively safe from the Tsunami's reach. The panic ended at 20.25 WIB when the BMKG withdrew the Tsunami early warning. Suppose previously the earthquake (29 July) was only felt on three islands (Lombok, Sumbawa and Bali). In that case, the earthquake shocks with a 7.0 SR were reported by the United States Geological Survey (USGS) and were felt throughout Lombok Island, Bali Island, Sumbawa Island, Madura, Eastern part of Java Island and parts of Sumba Island and Flores Island. The physical damage caused by the 5 August earthquake was increasingly widespread, previously primarily centred in North Lombok Regency, then evenly spread to East Lombok, West Lombok, and Mataram City Regencies. According to BPBD West Nusa Tenggara, the economic loss was estimated at Rp. 1 trillion as a result of this disaster. The calculation is based on the five affected sectors: housing, infrastructure, and productive economy [48].

Then, Thursday, 9 August 2018, at 12.25 WIB, another earthquake with $6.2 \mathrm{SR}$ was updated to $5.9 \mathrm{SR}$. This earthquake is a series of aftershocks from the main earthquake on 5 August 2018 [49]. It was not only finished there, on Sunday night, 19 August 2018, to be precise, at $21.56 \mathrm{WIB}$, but there was also another big earthquake with a magnitude of 7.0, which was updated to 6.9 SR by BMKG. This earthquake is a new major earthquake activity different from the main earthquake that occurred on 29 July, 5, and 9 August 2018; in other words, the 6.9 magnitude earthquake is not an aftershock from the previous earthquake [50]. According to data compiled from BMKG until 11 September 2018, aftershocks of smaller magnitude (see Figure 1) are still occurring. This series of earthquakes affected all forms of government activity, economic activity, and all activities of Lombok Island people as a whole.

\section{What Has Been Done?}

After being "terrorized" by a series of earthquakes that occurred for several months, the tourism industry's activity on the island of Lombok decreased significantly. Stakeholders in the tourism sector suffer because tourists cancel their reservations, and all 
domestic and foreign tourists who have been in Lombok choose to go elsewhere (e.g. Bali).

Post-earthquake Lombok is facing challenging times because it is in the reconstruction and repair stage as a whole, both from physical infrastructure, economic aspects, even aspects of human resources (community mentality), which are still overwhelmed by severe trauma related to the earthquake they faced. In this context, the government's financial support is needed for community collaboration after a disaster; this strategy is in line with resource-based theory [20], [32], [33], [34], [37].

Another issue that has arisen is the concern of various parties regarding the sustainability of Lombok Island tourism. Apart from Bali Island, Lombok Island is one of Indonesia's leading tourist destinations and has been designated by the Central Government as a Special Economic Zone for tourism development (www.itdc.co.id). An especially formidable challenge in managing post-disaster tourism destination recovery is restoring its image and reputation, which could be affected by harmful or inaccurate media coverage [52]-[56]. Media reports often have a farreaching impact on a tourist destination affected by a disaster and pose a severe challenge to its marketability [52].

The debate about the status of a disaster from the central government also became a polemic. Many parties have pushed for the Lombok earthquake to be upgraded to a National Disaster. However, the central government remains committed to giving optimal attention to recovery and reconstruction without increasing its status to a National Disaster. The government's decision can be seen from several points of view, one of which is a form of anticipation regarding the image and selling power of Lombok tourism in the future. Several studies have found a tendency for excessive coverage of a disaster. The significant impact of the damage will cause the tourist destination is selling power to decrease [52]. Perhaps this is why the Central Government (represented by the President of the Republic of Indonesia) does not want to make the Lombok Earthquake Disaster a National Disaster status. Because concerns about the image and selling power of Lombok tourism will be significantly disrupted, moreover Lombok is one of the Special Economic Zones with a leading sector, namely tourism. The government/state shows the very dominant nature of power to regulate policies that are deemed appropriate to maintain the stability and reputation of Lombok as a leading tourist destination is a representation of the political-based theory implemented by the central/state government.

Questions that will often arise after a disaster (in the context of Lombok tourism) include "how to encourage them to return?" The answer to this question can be understood through the following description. In the initial phase of disaster management, one of the central government policies (related to the tourism industry's stability) that is interesting to observe is the issuance of a policy to evacuate all foreign tourists out of Lombok. This policy should not be viewed from an opposing point of view. This policy has demonstrated responsive and anticipatory efforts by the government to maintain the tourism industry's stability. The government seems well aware that the response and delivery of prompt and appropriate services in a disaster are crucial indicators that receive serious attention from consumers of the tourism industry. These responsive and anticipatory efforts will give tourists a positive impression regarding their perceptions and beliefs in the government's role to support the comfort and safety of tourists. Of course, this will provide added value to the tourism sector in Indonesia in general. The positive perception of tourists regarding the safety and security factors they get allows them to avoid severe trauma, which causes them to have no longer worry about returning to visit post-disaster tourism areas. This case example reinforces the opinion expressed by these responsive and anticipatory efforts will give tourists a positive impression regarding their perceptions and beliefs in 
the government's role to support the comfort and safety of tourists. Of course, this will provide added value to the tourism sector in Indonesia in general. The positive perception of tourists regarding the safety and security factors they get allows them to avoid severe trauma, which causes them to have no longer worry about returning to visit post-disaster tourism areas. This case example reinforces the opinion expressed by these responsive and anticipatory efforts will give tourists a positive impression regarding their perceptions and beliefs in the government's role to support the comfort and safety of tourists. Of course, this will provide added value to the tourism sector in Indonesia in general. The positive perception of tourists regarding the safety and security factors they get allows them to avoid severe trauma, which causes them to have no longer worry about returning to visit post-disaster tourism areas. This case example reinforces the opinion expressed by Of course; this will provide added value for Indonesia's tourism sector in general. The positive perception of tourists regarding the safety and security factors they get allows them to avoid severe trauma, which causes them to have no longer worry about returning to visit post-disaster tourism areas. This case example reinforces the opinion expressed by this will provide added value for Indonesia's tourism sector in general. The positive perception of tourists regarding the safety and security factors they get allows them to avoid severe trauma, which causes them to have no longer worry about returning to visit post-disaster tourism areas. This case example strengthens the opinion expressed by Avraham [57] on the perception of disaster risk and Khazai et al. [55] related to planning, making and implementing proactive policies.

In October 2018, the NTB Provincial Development Planning Agency (Bappeda) discussed economic recovery strategies due to the Lombok-Sumbawa earthquake's impact as an effort to accelerate economic development. The tourism sector, which has implications for other sectors, focusing on human and institutional recovery, recovery of disasteraffected destinations, and marketing recovery, was not affected by the disaster [58]. The discussion involved various stakeholders, including the NTB Provincial Bappeda as the initiator, the NTB Provincial Tourism Office, representatives of the Mataram Tourism Workers Federation, the NTB Province Regional Tourism Promotion Board and representatives from the Academic element. The NTB Provincial Bappeda has also coordinated with the National Development Planning Agency to calculate the impact of the earthquake on NTB. Conditions as the start of new development planning in NTB and the division of authority between the centre and the regions in structuring tourist areas that pay attention to spatial aspects. Later, the coordination results with various stakeholders will contribute to becoming indicators in the initial draft of the 2019-2023 RPJMD.

\section{Next What To Do?}

Natural disasters can significantly affect the image of a tourism destination [55]. The negative impact of natural disasters not only dramatically affects the tourism sector in developing countries, but developed countries also face similar problems. For example, a significant flood that hit Australia's northern region, the tourism industry is faced with a significant challenge to restore its activities to normal conditions as the flood has not occurred [59]. However, something different happened in the 2004 Indian Ocean Tsunami case, after the Tsunami, where the international media's attention was so great it directly affected tourist visits after the Tsunami (several years later) after the main and supporting infrastructure were repaired or reconstructed [60]-[63].

Referring to the example of flooding in Australia's northern region, Faulkner and Vikulov [51] reported that the "Katherine Back On-track" campaign had resulted in significant short-term financial losses. Damage to the tourism business can also be caused by negative media coverage of the news and a ruined image of the destination [52], [55], [64]. As reminded 
by Khazai et al. [55], disasters can have long-term effects; repair and recovery are not only seen from the point of view of physical damage or efforts to rebuild infrastructure better. Nevertheless, attention to the affected community's psychology (reduce or eliminate trauma caused by the disaster) and rebuild confidence in the tourism market is a fundamental thing. This is why the obstacles are facing recovery are getting more extensive and more prolonged [65].

The government (both central and local) and actors in the tourism industry must have a measurable plan and suitable strategic management applications to deal with post-disaster recovery and recovery. For example, the UNWTO Handbook on Sustainable Development Indicators for Tourism Goals (as of 2004) was designed to help identify critical issues and indicators that decision-makers can use to respond effectively and sustain what makes tourist destinations more lively interesting [66]. Regrettably, however, the existing documents do not adequately describe destination safety or disaster resilience, both of which are central to a sustainable tourism sector [55]. After examining some of the existing research on crisis indicators on sustainable tourism, Khazai et al. [55] concluded the research trend focused on identifying indicators that monitor the negative impacts of tourism at the destination rather than indicators measuring recovery after a disaster. On the other hand, research on risk reduction by offering various disaster recovery indicator frameworks with many variations in structure, content and complexity has been proposed and applied [67]-[70].

Several experts suggest that crisis communication strategies in managing risk perceptions must be carried out correctly [57], [71]. Perceptions of risk are managed in such a way as to produce a view that does not lead to negative forms, this is what all stakeholders should strive for. This strategy will be effective if the communication plan is integrated with risk management policies and strategies [66]. The tourism industry follows up by communicating positive messages that can increase the tourism market's confidence (domestic and foreign tourists) [71]-[73]. In other words, proactive policymaking, good planning and implementation are likely to increase the sector's ability to recover from crises and disasters [55].

Another post-disaster effort to "push them back" is to provide up-to-date information on the safety and status of infrastructure, attractions, accommodation, restaurants and other facilities and ensure tourists are aware of unaffected areas so that they have alternative destinations in areas that are not affected [55]. It is important to note that access to objective and reliable information is also beneficial in countering the adverse effects of the media overreporting the disaster experienced and ensuring visitors can make choices based on the information provided [55].

\section{CONCLUSION}

The earthquake that hit West Nusa Tenggara, especially on the island of Lombok, had a severe impact on several main sectors, such as housing, infrastructure, productive economy, socio-culture, and other cross-sectors. This paper pays special attention to the productive economy where the island of Lombok has long been recognized as a leading tourist destination in Indonesia. Post-disaster collaboration from stakeholders, both government/state and tourism industry players and the public in general, needs to be seriously initiated and facilitated to support the acceleration of the postearthquake rehabilitation and reconstruction process.

The government has carried out responsive handling, countermeasures and first aid. This shows the government's seriousness in the disaster management process, which subsequently received positive appreciation from the domestic community and the international community. However, some notes need attention to improve and anticipate if a similar incident occurs again in the future. We think that the government's policies (both central and local) have 
also been by the conditions and urgency of the problems at hand.

The economic recovery program due to the impact of the Lombok earthquake is still ongoing, especially the tourism sector, which has implications for other sectors, with a focus on restoring human and institutional resources and restoring disaster-affected destinations (both physical and non-physical). A sizeable budget has been allocated to support this recovery. Thus, the tourism industry's government and actors must have a measurable plan and suitable strategic management applications to handle postdisaster recovery and recovery. Finally, we suggest that disaster management principles should be integrated into destination management plans to increase tourist destinations' resilience against natural disasters.

\section{REFERENCES}

[1]. S. Maryanti, I. G. A. O. Netrawati, D. Martini, and F. H. Sukmana, "Halal Tourism In West Nusa Tenggara: A Legal And Economic Perspective," Jurnal IUS Kajian Hukum dan Keadilan, vol. 8, no. 3, Art. no. 3, Dec. 2020, doi: 10.29303/ius.v8i3.827.

[2]. www.wttc.org, "World Travel \& Tourism Council," 2019. https://www.wttc.org/.

[3]. J. C. Carlsen and M. Hughes, "Tourism Market Recovery in the Maldives After the 2004 Indian Ocean Tsunami," Journal of Travel \& Tourism Marketing, vol. 23, no. 2-4, pp. 139-149, Jan. 2008, doi: 10.1300/J073v23n02_11.

[4]. J. Henderson, "Managing a Tourism Crisis in Southeast Asia," International Journal of Hospitality \& Tourism Administration, vol. 3, no. 1, pp. 85-105, Jan. 2002, doi: 10.1300/J149v03n01_05.

[5]. Y. Jiang and B. W. Ritchie, "Disaster collaboration in tourism: Motives, impediments and success factors," Journal of Hospitality and
Tourism Management, vol. 31, pp. 70-82, Jun. 2017, doi: 10.1016/j.jhtm.2016.09.004.

[6]. UNISDR, "The economic and human impact of disaster in the last 10 years," www.unisdr.org, 2015.

https://www.unisdr.org/we/inform/disasterstatistics (accessed May 07, 2019).

[7]. UNISDR, "2009 UNISDR terminology on disaster risk reduction," www.unisdr.org, 2009. http://www.unisdr.org/files/7817_UNISDRTer minologyEnglish.pdf.

[8]. E. Laws and B. Prideaux, "Crisis Management: A Suggested Typology," Journal of Travel \& Tourism Marketing, vol. 19, no. 2-3, pp. 1-8, Jun. 2005, doi: 10.1300/J073v19n02_01.

[9]. N. Evans and S. Elphick, "Models of crisis management: an evaluation of their value for strategic planning in the international travel industry," International Journal of Tourism Research, vol. 7, no. 3, pp. 135-150, 2005, doi: 10.1002/jtr.527.

[10]. C. Orchiston and J. E. S. Higham, "Knowledge management and tourism recovery (de)marketing: the Christchurch earthquakes 2010-2011," Current Issues in Tourism, vol. 19, no. 1, pp. 64-84, Jan. 2016, doi: 10.1080/13683500.2014.990424.

[11]. P. Racherla and C. Hu, "A Framework for Knowledge-Based Crisis Management in the Hospitality and Tourism Industry," Cornell Hospitality Quarterly, vol. 50, no. 4, pp. 561577, Nov. 2009, doi: $10.1177 / 1938965509341633$.

[12]. disbudpar.ntbprov.go.id, "Dinas Pariwisata Provinsi NTB» Pesona Lombok Sumbawa." http://www.disbudpar.ntbprov.go.id/ (accessed May 07, 2019).

[13]. T. B. Jamal and A. Stronza, "Collaboration theory and tourism practice in protected areas: stakeholders, structuring and sustainability," Journal of Sustainable Tourism, vol. 17, no. 2, 
pp. 169-189, Mar. 2009, doi: 10.1080/09669580802495741.

[14]. W. L. Waugh and G. Streib, "Collaboration and Leadership for Effective Emergency Management," vol. 66, no. 1, pp. 131-140, Nov. 2006, doi: https://doi.org/10.1111/j.15406210.2006.00673.x.

[15]. J. (Bill) Xu and A. Grunewald, "What Have We Learned? A Critical Review of Tourism Disaster Management," Journal of China Tourism Research, vol. 5, no. 1, pp. 102-130, Mar. 2009, doi: $10.1080 / 19388160802711444$.

[16]. B. Gray and D. J. Wood, "Collaborative Alliances: Moving from Practice to Theory," The Journal of Applied Behavioral Science, vol. 27, no. 1, pp. 3-22, Mar. 1991, doi: $10.1177 / 0021886391271001$.

[17]. O. Renn, "Stakeholder and Public Involvement in Risk Governance," Int J Disaster Risk Sci, vol. 6, no. 1, pp. 8-20, Mar. 2015, doi: 10.1007/s13753-015-0037-6.

[18]. H. Saito and L. Ruhanen, "Power in tourism stakeholder collaborations: Power types and power holders," Journal of Hospitality and Tourism Management, vol. 31, pp. 189-196, Jun. 2017, doi: 10.1016/j.jhtm.2017.01.001.

[19]. S. Curnin, "Collaboration in disasters: A cultural challenge for the utilities sector," Utilities Policy, vol. 54, pp. 78-85, Oct. 2018, doi: 10.1016/j.jup.2018.08.002.

[20]. L. Pennington-Gray, I. Cahyanto, A. Schroeder, and A. Kesper, "Collaborative communication networks: an application in Indonesia.," Tourism crisis and disaster management in the Asia-Pacific, pp. 77-94, 2015.

[21]. B. W. Ritchie, "Chaos, crises and disasters: a strategic approach to crisis management in the tourism industry," Tourism Management, vol. 25, no. 6, pp. 669-683, Dec. 2004, doi: 10.1016/j.tourman.2003.09.004.

[22]. M. Volgger and H. Pechlaner, "Requirements for destination management organizations in destination governance: Understanding DMO success," Tourism Management, vol. 41, pp. 6475, Apr. 2014, doi: 10.1016/j.tourman.2013.09.001.

[23]. C. Ansell and A. Gash, "Collaborative Governance in Theory and Practice," J Public Adm Res Theory, vol. 18, no. 4, pp. 543-571, Oct. 2008, doi: 10.1093/jopart/mum032.

[24]. G. Simo, "Sustaining Cross-Sector Collaborations: Lessons from New Orleans," Public Organ Rev, vol. 9, no. 4, p. 367, Nov. 2009, doi: 10.1007/s11115-009-0091-x.

[25]. S. Selin and D. Chavez, "Developing an evolutionary tourism partnership model," Annals of Tourism Research, vol. 22, no. 4, pp. 844-856, Jan. 1995, doi: 10.1016/01607383(95)00017-X.

[26]. B. Bramwell and A. Sharman, "Collaboration in local tourism policymaking," Annals of Tourism Research, vol. 26, no. 2, pp. 392-415, Apr. 1999, doi: 10.1016/S0160-7383(98)00105-4.

[27]. S. Graci, "Collaboration and Partnership Development for Sustainable Tourism," Tourism Geographies, vol. 15, no. 1, pp. 25-42, Feb. 2013, doi: 10.1080/14616688.2012.675513.

[28]. T. B. Jamal and D. Getz, "Collaboration theory and community tourism planning," Annals of Tourism Research, vol. 22, no. 1, pp. 186-204, Jan. 1995, doi: 10.1016/0160-7383(94)00067-3.

[29]. D. Waayers, D. Lee, and D. Newsome, "Exploring the nature of stakeholder collaboration: a case study of marine turtle tourism in the Ningaloo region, Western Australia," Current Issues in Tourism, vol. 15, no. 7, pp. 673-692, Sep. 2012, doi: 10.1080/13683500.2011.631697.

[30]. P. W. Hystad and P. C. Keller, "Towards a destination tourism disaster management framework: Long-term lessons from a forest fire disaster," Tourism Management, vol. 29, no. 1, pp. 151-162, Feb. 2008, doi: 10.1016/j.tourman.2007.02.017. 
[31]. M. R. Scarpino and U. Gretzel, "Conceptualizing organizational resilience in tourism crisis management.," Tourism crisis and disaster management in the Asia-Pacific, pp. 15-32, 2015.

[32]. A. Fyall, B. Garrod, and Y. Wang, "Destination collaboration: A critical review of theoretical approaches to a multi-dimensional phenomenon," Journal of Destination Marketing \& Management, vol. 1, no. 1, pp. 1026, Nov. 2012, doi: 10.1016/j.jdmm.2012.10.002.

[33]. L. Pennington-Gray, A. Schroeder, and T. Gale, "Co-management as a Framework for the Development of a Tourism Area Response Network in the Rural Community of Curanipe, Maule Region, Chile," Tourism Planning \& Development, vol. 11, no. 3, pp. 292-304, Jul. 2014, doi: 10.1080/21568316.2014.890124.

[34]. L. Cioccio and E. J. Michael, "Hazard or disaster: Tourism management for the inevitable in Northeast Victoria," Tourism Management, vol. 28, no. 1, pp. 1-11, Feb. 2007, doi: 10.1016/j.tourman.2005.07.015.

[35]. G. N. Nyaga, J. M. Whipple, and D. F. Lynch, "Examining supply chain relationships: Do buyer and supplier perspectives on collaborative relationships differ?," Journal of Operations Management, vol. 28, no. 2, pp. 101-114, Mar. 2010, doi: 10.1016/j.jom.2009.07.005.

[36]. J. E. Sowa, "The Collaboration Decision in Nonprofit Organizations: Views From the Front Line," Nonprofit and Voluntary Sector Quarterly, vol. 38, no. 6, pp. 1003-1025, Dec. 2009, doi: 10.1177/0899764008325247.

[37]. S. Beeton, "Horseback Tourism in Victoria, Australia: Cooperative, Proactive Crisis Management," Current Issues in Tourism, vol. 4, no. 5, pp. 422-439, Oct. 2001, doi: 10.1080/13683500108667897.
[38]. A. Fyall and B. Garrod, Tourism Marketing: A Collaborative Approach. Clevedon; Buffalo: Channel View Publications, 2004.

[39]. C. Guo and M. Acar, "Understanding Collaboration Among Nonprofit Organizations: Combining Resource Dependency, Institutional, and Network Perspectives," Nonprofit and Voluntary Sector Quarterly, vol. 34, no. 3, pp. 340-361, Sep. 2005, doi: $10.1177 / 0899764005275411$.

[40]. P. Kelly, "Political Theory - The State of the Art,” Politics, vol. 26, no. 1, pp. 47-53, Feb. 2006, doi: 10.1111/j.1467-9256.2006.00250.x.

[41]. A. Fyall, B. Oakley, and A. Weiss, "Theoretical Perspectives Applied to Inter-Organisational Collaboration on Britain's Inland Waterways," International Journal of Hospitality \& Tourism Administration, vol. 1, no. 1, pp. 89-112, Jan. 2000, doi: 10.1300/J149v01n01_06.

[42]. M. Howes et al., "Towards networked governance: improving interagency communication and collaboration for disaster risk management and climate change adaptation in Australia," Journal of Environmental Planning and Management, vol. 58, no. 5, pp. 757-776, May 2015, doi: 10.1080/09640568.2014.891974.

[43]. J. Jesson, L. Matheson, and F. M. Lacey, Doing Your Literature Review: Traditional and Systematic Techniques. SAGE Publications Ltd, 2011.

[44]. L. A. Machi and B. T. McEvoy, The Literature Review: Six Steps to Success, 3rd ed. SAGE Publications, 2016.

[45]. BMKG, "Gempabumi Terkini | BMKG," BMKG | Badan Meteorologi, Klimatologi, dan Geofisika, 2018. https://www.bmkg.go.id/gempabumi/gempabu mi-terkini.bmkg (accessed Sep. 10, 2018).

[46]. www.bbc.com, "Gempa Lombok: Sebanyak 1.226 pendaki telah dievakuasi dari Gunung Rinjani,” BBC News Indonesia, Aug. 01, 2018. 
[47]. id.wikipedia.org, "Gempa bumi Lombok Juli 2018 - Wikipedia bahasa Indonesia, ensiklopedia bebas." 2018, Accessed: Aug. 30, 2018. Online]. Available: https://id.wikipedia.org/wiki/Gempa_bumi_Lo mbok_Juli_2018.

[48]. id.wikipedia.org, "Gempa bumi Lombok 5 Agustus 2018," Wikipedia bahasa Indonesia, ensiklopedia bebas. Aug. 19, 2018, Accessed: Aug. 30, 2018. Online]. Available: https://id.wikipedia.org/w/index.php?title=Gem pa_bumi_Lombok_5_Agustus_2018\&oldid=141 21942.

[49]. BMKG, "Ulasan Guncangan Tanah Akibat Gempa Lombok Utara 09 Agustus 2018 | BMKG," BMKG | Badan Meteorologi, Klimatologi, dan Geofisika, Aug. 09, 2018. http://www.bmkg.go.id/berita/?p=ulasanguncangan-tanah-akibat-gempa-lombok-utara09-agustus-2018\&tag=\&lang=ID (accessed Aug . $30,2018)$.

[50]. BMKG, "Ulasan Guncangan Tanah Akibat Gempabumi Lombok Timur 19 Agustus 2018 | BMKG," BMKG | Badan Meteorologi, Klimatologi, dan Geofisika, Aug. 21, 2018. $? \mathrm{p}=$ ulasan-guncangan-tanah-akibatgempabumi-lombok-timur-19-agustus2018\&tag=ulasan-guncangan-tanah\&lang=ID (accessed Aug. 30, 2018).

[51]. www.itdc.co.id, "Indonesia Tourism Development Corporation." https://www.itdc.co.id/mandalika/beranda/ (accessed Sep. 10, 2018).

[52]. D. Beirman, "Safety and security in tourism recovery marketing after crises," Journal of Policy Research in Tourism, Leisure and Events, vol. 8, no. 1, pp. 98-106, Jan. 2016, doi: 10.1080/19407963.2015.1083339.

[53]. K. Cassedy, Crisis Management Planning in the Travel and Tourism Industry: A Study of Three Destination Cases and a Crisis Management
Planning Manual. Pacific Asia Travel Association, 1991.

[54]. T. E. Drabek, "Variations in Disaster Evacuation Behavior: Public Responses Versus Private Sector Executive Decision-Making Processes," Disasters, vol. 16, no. 2, pp. 104-118, Jun. 1992, doi: 10.1111/j.1467-7717.1992.tb00384.x.

[55]. B. Khazai, F. Mahdavian, and S. Platt, "Tourism Recovery Scorecard (TOURS) - Benchmarking and monitoring progress on disaster recovery in tourism destinations," International Journal of Disaster Risk Reduction, vol. 27, pp. 75-84, Mar. 2018, doi: 10.1016/j.ijdrr.2017.09.039.

[56]. P. E. Murphy and R. Bayley, "Tourism and Disaster Planning," Geographical Review, vol. 79, no. 1, pp. 36-46, 1989, doi: 10.2307/215681.

[57]. E. Avraham, "Destination image repair during crisis: Attracting tourism during the Arab Spring uprisings," Tourism Management, vol. 47, pp. 224-232, Apr. 2015, doi: 10.1016/j.tourman.2014.10.003.

[58]. R. Admara, "Strategi Percepatan Pemulihan Ekonomi Pariwisata Pasca Bencana Gempa Bumi Lombok-Sumbawa," BAPPEDA PROVINSI NTB, Oct. 02, 2018. https://bappeda.ntbprov.go.id/strategipercepatan-pemulihan-ekonomi-pariwisatapasca-bencana-gempa-bumi-lombok-sumbawa/ (accessed Jun. 06, 2019).

[59]. B. Faulkner and S. Vikulov, "Katherine, washed out one day, back on track the next: a postmortem of a tourism disaster," Tourism Management, vol. 22, no. 4, pp. 331-344, Aug. 2001, doi: 10.1016/S0261-5177(00)00069-8.

[60]. J. Ichinosawa, "Reputational disaster in Phuket: the secondary impact of the tsunami on inbound tourism," Disaster Prev and Management, vol. 15, no. 1, pp. 111-123, Jan. 2006, doi: 10.1108/09653560610654275.

[61]. Tourism Concern, "Post tsunami reconstruction and tourism - a second disaster," 2005. https://www.tourismconcern.org.uk/rememberi 
ng-the-tsunami/post-tsunami-reconstructionand-tourism-a-second-disaster/ (accessed Sep. 02, 2018).

[62]. UNDP, "Survivors of the tsunami, one year later: UNDP assisting communities to build back better," 2005. https://www.preventionweb.net/publications/vi ew/2083 (accessed Sep. 02, 2018).

[63]. T. Wachtendorf, J. M. Kendra, H. Rodríguez, and J. Trainor, "The Social Impacts and Consequences of the December 2004 Indian Ocean Tsunami: Observations from India and Sri Lanka," Earthquake Spectra, vol. 22, no. S3, pp. 693-714, Jun. 2006, doi: 10.1193/1.2202650.

[64]. S. F. Sönmez, Y. Apostolopoulos, and P. Tarlow, "Tourism in Crisis: Managing the Effects of Terrorism," Journal of Travel Research, vol. 38, no. 1, pp. 13-18, Aug. 1999, doi: 10.1177/004728759903800104.

[65]. B. Faulkner, "Towards a framework for tourism disaster management," Tourism Management, vol. 22, no. 2, pp. 135-147, Apr. 2001, doi: 10.1016/S0261-5177(00)00048-0.

[66]. UNWTO, "Sustainable tourism indicators and destination manangement. Regional workshop Kolašin, Montenegro 25-27 April World Tourism Organisation, 2007,” 2007. Online]. Available:

https://sdt.unwto.org/sites/all/files/pdf/finrep.pd f.

[67]. D. Brown, S. Platt, and J. Bevington, Disaster Recovery Indicators: guidelines for monitoring and evaluation. Cambridge University Centre for Risk in the Built Environment, 2010.

[68]. S. E. Chang, "Urban disaster recovery: a measurement framework and its application to the 1995 Kobe earthquake," Disasters, vol. 34, no. 2, pp. 303-327, Apr. 2010, doi: 10.1111/j.1467-7717.2009.01130.x.

[69]. S. B. Miles and S. E. Chang, "Modeling Community Recovery from Earthquakes,"
Earthquake Spectra, vol. 22, no. 2, pp. 439-458, May 2006, doi: 10.1193/1.2192847.

[70]. S. Platt and B. D. Drinkwater, "Post-earthquake decision making in Turkey: Studies of Van and İzmir," International Journal of Disaster Risk Reduction, vol. 17, pp. 220-237, Aug. 2016, doi: 10.1016/j.ijdrr.2016.03.010.

[71]. W. T. Coombs, Ongoing Crisis Communication: Planning, Managing, and Responding. SAGE Publications, Inc, 2014.

[72]. J. Mair, B. W. Ritchie, and G. Walters, "Towards a research agenda for post-disaster and post-crisis recovery strategies for tourist destinations: a narrative review," Current Issues in Tourism, vol. 19, no. 1, pp. 1-26, Jan. 2016, doi: 10.1080/13683500.2014.932758.

[73]. W. B. Young and R. J. Montgomery, "Crisis Management and Its Impact on Destination Marketing," Journal of Convention \& Exhibition Management, vol. 1, no. 1, pp. 3-18, Oct. 1997, doi: 10.1300/J143v01n01_02.

\section{Cite this article as :}

Sri Maryanti, I Gusti Ayu Oka Netrawati, I Gusti Putu Bagus Suastina, Febrian Humaidi Sukmana, Dwi Martini, "Post-Disaster Mitigation and Recovery in Tourism Destinations: Learning from The Lombok Earthquake", International Journal of Scientific Research in Science and Technology (IJSRST), Online ISSN : 2395-602X, Print ISSN : 2395-6011, Volume 8 Issue 2, pp. 571-584, March-April 2021. Available at doi $\quad$ : https://doi.org/10.32628/IJSRST218297

Journal URL : https://ijsrst.com/IJSRST218297 